\section{SOI: 1.1/TAS DOI: 10.15863/TAS International Scientific Journal Theoretical \& Applied Science}

p-ISSN: 2308-4944 (print) e-ISSN: 2409-0085 (online)

Year: $2017 \quad$ Issue: $11 \quad$ Volume: 55

Published: 21.11.2017ｈttp://T-Science.org

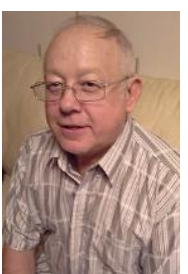

Sergey Petrovich Ivanenkov

$\mathrm{PhD}$, Professor

The Saint Petersburg State Institute

of Psychology and Social Work

Saint Petersburg, Russian Federation credonew@yandex.ru

Section 30. Philosophy

\title{
STUDYING THE CATEGORY OF COMPETITION AS A SOCIO- PHILOSOPHICAL PHENOMENON
}

\author{
Abstract: In this article, some questions of socio-philosophical analysis of the category of competition, its \\ types, modes and forms are considered. \\ Key words: competition, subjectness, culture, society, social philosophy, gnoseological and ontological \\ content of competition, human activity, human factor, youth. \\ Language: English \\ Citation: Ivanenkov SP (2017) STUDYING THE CATEGORY OF COMPETITION AS A SOCIO- \\ PHILOSOPHICAL PHENOMENON. ISJ Theoretical \& Applied Science, 11 (55): 85-88. \\ Soi: http://s-o-i.org/1.1/TAS-11-55-11 Doi: crossef https://dx.doi.org/10.15863/TAS.2017.11.55.11
}

\section{Introduction}

The category of competition in the modern philosophical tradition is not sufficiently studied. The notions of competition fit into the framework of economic, political or sociological science. However, is it possible to talk about a full study of this phenomenon without taking into account the philosophical features of the examination? Of course no.

Competition in the emergence of a new social reality characterizes both the objective reality and its reflection in the forms of the subject's activity-social subjectness. In this case, there are situations with many unknowns that put the subject before the need for choice. Competition - is the mechanism that makes it possible to quantify and qualitatively determine the degree of probability of a particular result, and is also a way of removing uncertainty, by making practical opportunities for reality, resolving contradictions in the course of a multivariate development of events.

\section{Materials and Methods}

The study of competition without taking into account the cultural characteristics of the social reality in which it occurs cannot adequately interpret the dynamics of the development of transitional societies. Theoretical concepts devoted to the study of competition do not develop specific mechanisms for realizing social transformations. Therefore, it is necessary to identify and analyze the factors affecting the social space of competition and its role in the implementation of adaptation strategies, both at the group and individual levels.

Sociocultural approach means that competition, being a mechanism for the emergence of a new social reality, always concerns the value solution, being an indispensable element of any choice. Therefore, the analysis of the value bases of competition will allow us to trace the dynamics of the formation of the one or the value dominant that determines the adaptation strategy, as well as to identify the conditions, factors, resources and criteria for social adaptation in a transforming society.

The problem of competition has long been fruitfully studied by various sciences, nevertheless, attempts to analyze the phenomenon of competition lead to a number of unresolved issues. First, it concerns the definition of the concept itself. Most researchers agree that competition is a form of activity in conditions of uncertainty, if possible, to assess the probability of its outcome.

For example, the researcher from Uzbekistan Shahnoza Negmatova in her publications singles out a number of features of considering competition as a philosophical phenomenon [9, p. 92-93].

Sh.Negmatova substantiates the ontological nature of the concept of competition, reveals its gnoseological content based on mental features, and also substantiates the role of competition in improving the methods of managing society, the dynamics of its transformation into an important element of democratic governance of society. In her 
opinion, competition can be characterized by spatiotemporal indicators with a division into such types as competition in the biosphere and competition in the noosphere.

It is interesting to note that Sh.Neghmatova paid much attention to the study of moral laws for the improvement of economic competition, as well as the norms and principles of its implementation, and substantiates the dialectical regularity of healthy spiritual competition, improving methodological approaches and means of forming spiritual competitiveness.

Today, social and humanitarian sciences affirm the awareness of society and nature as functionally equal parts of a single whole that can exist in this capacity provided that human actions are correlated with the capabilities of the natural environment. This leads to a qualitative transformation in the interpretation of the category "competition", because initially competition is "a biological problem as a struggle for existence" [3, p. eleven]. The study of the phenomena of competition in natural conditions, i.e. the recognition of competition immanently present in nature, subsequently allowed identifying and evaluating it with the help of scientific methods, and then including in its definitions social aspects $[10$, p. 4]. The human factor in this case was considered primarily as the ability to lose or win, i.e. as a competitiveness. In their relation to competition, individuals were divided into two categories: those striving to avoid competition (risk) and prone to competition. Competitiveness in the eyes of supporters of these approaches is directly related to the ability to effectively prevent possible losses. In this interpretation, competitiveness is included in the meaning of such concepts as "chance", "luck", "courage" [10, p. 5].

Awareness of the situation of competition allows the subject to "remove" it by selecting and implementing one of the available alternatives. This is achievable in conditions of a full or sufficiently definite field of possibilities, in which the reliability of risk assessment increases through the ratio of the probabilities of winning and losing $[10$, p. 5]. Thus, competition is defined as a situational characteristic of the activity, consisting in the uncertainty of its outcome and in possible adverse consequences in case of failure. Moreover, the uncertainty of the outcome of the competitive action does not at all mean the uncertainty of the situation in general, but rather indicates its probabilistic nature, in which success depends on the degree of certainty of possibilities, i.e. competitiveness of the subject or society $[10$, p. 6].

The content of the phenomenon of competition implies a variety of forms of its existence, since competition is not only an activity, but also a characteristic of the state of the individual, group, society. By now, there is already quite a wide range of socio-philosophical, socio-psychological and psychological works devoted to this problem.

Competition becomes the most common characteristic of modern society. Social actors acquire the ability not only to overcome, with varying degrees of success, the state of uncertainty, but also to reproduce competition at the individual and societal levels. At the same time, the forms in which competition is produced differ in specific adaptation strategies. As it was shown in the research, in the demographic situation, at the stage of life launch, in social self-realization, in the system of the value hierarchy are not identical.

Analysis of the phenomenon of competition in the philosophical, economic, psychological and legal subject field showed that there was an urgent need for the development of mechanisms and technologies that adapt a person to life in a transitional society. The development of a competition society is accompanied by a change in its internal structure, a radical transformation of nature and the role of social groups, the family, the tender, the profession, etc. Therefore, the basis for structuring adaptation strategies determined by the competitiveness of social and personal resources is changing, they become more complex and more time-consuming than those characteristic of a stable society. The presence of positive dynamics in this direction can be judged already by the fact that modern competition societies do not massively produce extreme models of behavior, and existence in a competitive environment generates a generally more pragmatic and balanced attitude in the choice of adaptation strategies. The analysis of the dynamics of social adaptation in the conditions of competition made it possible to reveal some regularities typical for the present stage of development of social subjectness of the youth socio-demographic group. Thus, the general reproductive causes of competition, for example, in the youth environment include unemployment in the labor market, inequality in the opportunities for acquiring it in education, the disintegration of the traditional family in the family, and lower competitiveness in business. This is reflected in the typology of emerging conflicts between the socio-demographic group (youth) and society, which are associated with age discrimination, contradictions with the institutions of socialization and the global youth subculture.

Thus, it is possible to generalize and isolate the main types of competition that are characteristic of a particular socio-demographic group. The first type of competition concerns the positive and negative conditions of the demographic reproduction of vital forces, i.e. the man himself. Here there are social consequences of competition associated with the threat to health and life. If society does not create conditions for the physical development of young people, to protect its health and safety of life, there 
are real grounds for competition with a view to survival. In such a situation, there is a risk of falling behind in its development, acquiring chronic diseases, losing health. In the public sphere, the possibility of negative demographic reproduction increases.

The second type of competition is related to the inequality of the starting positions in the implementation of adaptation strategies determined by the inequality of social and personal resources of competitiveness. The lower the ascriptive status of young people, inherited from parents, the greater the uncertainty of the possibilities for choosing their own way of life. If for graduates from high-status families starting positions in school, in work, in the creation of their own family are a kind of springboard, then for all others - the equalization of the opportunities for a life start is determined either by one's own abilities, diligence, enterprise, or assistance from the state. In the absence of a purposeful social policy, necessary guarantees and well-thought-out social protection measures, inequalities of starting positions are amplified, the consequences of which are able to determine the whole further life.

The third type of competition is related to value-normative uncertainty. Values and norms play a decisive role in the integration of any society, giving a stable and irreversible character to social ties. In the individual-personal plan they are a kind of core on which the entire inner world of man is based. In a competition society with its uncertainty and unpredictability, there is a significant deformation of this mechanism. Traditional social values are devalued and replaced by group values, the system of institutional norms is destroyed, new values and norms are either rejected or cannot be realized with full or partial agreement with them.

The fourth type of competition is associated with the uncertainty of identity. The process of integrating social actors into society is not limited to their mechanical inclusion in public structures, but is accompanied by internal identification with them. This gives the process a stable character. Therefore, in an effort to stabilize and preserve its integrity, society is interested in reproducing the foundations of identity. However, under conditions of instability or transitional periods, traditional identification is being destroyed; new adaptation models are emerging, often with a destructive orientation.

\section{Conclusion}

Thus, in the conditions of a transforming society, competition becomes an integral part of social reality, the need for adaptation to which is inevitable for both social groups and actors. On the one hand, the uncertainty of opportunities to obtain the desired education, the acquisition of a good profession and interesting work, promotion, solving material problems, through professional activity, expands the space of competition. On the other hand, the desire to overcome this uncertainty, to break out of its bonds often define a passive-adaptive strategy of behavior, which manifests itself in the unwillingness to compete, defend its positions, preferring to wait and adjust.

\section{References:}

1. Azoev G.L. (1996) Konkurenciya: analiz, strategiya i praktika / G.L. Azoev. - M.: Centr ekonomiki i marketinga, 1996. - 207 p.

2. Belousova N.I. (2013) Metodologicheskie aspekty analiza konkurentosposobnyh estestvenno-monopol'nyh rynkov i mekhanizmov ih razvitiya / N I. Belousova, E.M. Vasil'eva // Vestnik RGNF. - 2013. - № 1. - p. 56-65.

3. Gauze G.F. (2002) Bor'ba za sushchestvovanie M - Izhevsk In-t komp'yuternyh issledovaniy, 2002, p. 11.

4. (2013) Teoriya i praktika povysheniya social'noy aktivnosti molodezhi: monografiya / A.V. Kostrikin, S.P. Ivanenkov. - SPb.: FGBOUVPO «SPGUTD», 2013. - 174 p.
5. Ivanenkov S.P. (2011) Problemy socializacii sovremennoy molodezhi. (Osnovnye tendencii i perspektivy razvitiya). - Izd-vo Lambert Akademic Publishing, 2011.

6. (2014) Dosug sovremennoy molodezhi : po materialam sociologicheskogo issledovaniya / S. P. Ivanenkov, M. K. Selezneva, E. S. Berkovchenko; pod red. S. P. Ivanenkova. SPb., 2014. - 120 p.

7. Kashpur V.V. (2007) Ponyatie «konkurenciya» $\mathrm{v}$ issledovaniyah sistemy obrazovaniya: metodologicheskie osnovaniya primeneniya // Vestnik Tomskogo gosudarstvennogo universiteta. 2007. № 298. p.242.

8. Mizes L.-fon (2000) Chelovecheskaya deyatel'nost': traktat po ekonomicheskoy teorii / 


\begin{tabular}{l|lrl|l|ll} 
& ISRA (India) & $=\mathbf{1 . 3 4 4}$ & SIS (USA) & $=\mathbf{0 . 9 1 2}$ & ICV (Poland) & $=\mathbf{6 . 6 3 0}$ \\
Impact Factor: & ISI (Dubai, UAE) $=\mathbf{0 . 8 2 9}$ & PUHL (Russia) $=\mathbf{0 . 2 0 7}$ & PIF (India) & $=\mathbf{1 . 9 4 0}$ \\
& GIF (Australia) & $\mathbf{0 . 5 6 4}$ & ESJI (KZ) & $=3.860$ & IBI (India) & $=\mathbf{4 . 2 6 0}$ \\
& JIF & $\mathbf{1 . 5 0 0}$ & SJIF (Morocco) & $=\mathbf{2 . 0 3 1}$ & & \\
\hline
\end{tabular}

L.-fon Mizes; per. s ang. A.V. Kuryaeva. - M.: Ekonomika, 2000. - 878 p.

9. Negmatova Sh. (2017) Ontologicheskaya priroda i gnoseologicheskie osobennosti konkurencii // Zh. «Imom Buhoriy saboқlari» («Uroki Imama Buhari»), 2017, №1. p. 92-93
10. Yangirova S.M. (2006) Konkurenciya i social'naya adaptaciya v transformiruyushchemsya obshchestve: social'no-filosofskiy analiz. Avtoreferat dissertacii na soiskanie uchyonoy stepeni kandidata filosofskih nauk. Ufa, 2006. -27 p. 